\title{
Refinement of the karyological aspects of Psidium guineense (Swartz, 1788): a comparison with Psidium guajava (Linnaeus, 1753)
}

\author{
Anelise Machado Marques', Amélia Carlos Tuler², Carlos Roberto Carvalho³, \\ Tatiana Tavares Carrijo ${ }^{4}$, Marcia Flores da Silva Ferreira ${ }^{5}$, \\ Wellington Ronildo Clarindo'
}

\begin{abstract}
I Laboratório de Citogenética, Departamento de Biologia, Centro de Ciências Agrárias, Universidade Federal do Espirito Santo, CEP: 29.500-000 Alegre - ES, Brazil 2 Escola Nacional de Botânica Tropical, Instituto de Pesquisas Jardim Botânico do Rio de Janeiro, CEP: 22.460-036 Rio de Janeiro-RJ, Brazil 3 Laboratório de Citogenética e Citometria, Departamento de Biologia Geral, Centro de Ciências Biológicas e da Saúde, Universidade Federal de Viçosa, CEP: 36.570-000 Viçosa - MG, Brazil 4 Laboratório de Botânica, Departamento de Biologia, Centro de Ciências Agrárias, Universidade Federal do Espirito Santo, CEP: 29.500-000 AlegreES, Brazil 5 Laboratório de Genética e Melhoramento Vegetal, Departamento de Biologia, Centro de Ciências Agrárias, Universidade Federal do Espirito Santo, CEP: 29.500-000 Alegre-ES, Brazil
\end{abstract}

Corresponding author: Wellington Ronildo Clarindo (welbiologo@gmail.com)

Academic editor: V. Lukhtanov | Received 3 September 2015 | Accepted 9 December 2015 | Published 2 February 2016

http://zoobank.org/99C0714D-5A99-4405-9479-D0C3D9EA74CD

Citation: Marques AM, Tuler AC, Carvalho CR, Carrijo TT, Ferreira MRS, Clarindo WR (2016) Refinement of the karyological aspects of Psidium guineense (Swartz, 1788): a comparison with Psidium guajava (Linnaeus, 1753). Comparative Cytogenetics 10(1): 117-128. doi: 10.3897/CompCytogen.v10i1.6462

\begin{abstract}
Euploidy plays an important role in the evolution and diversification of Psidium Linnaeus, 1753. However, few data about the nuclear DNA content, chromosome characterization (morphometry and class) and molecular markers have been reported for this genus. In this context, the present study aims to shed light on the genome of Psidium guineense Swartz, 1788, comparing it with Psidium guajava Linnaeus, 1753. Using flow cytometry, the nuclear $2 \mathrm{C}$ value of $P$. guineense was $2 \mathrm{C}=1.85$ picograms $(\mathrm{pg})$, and the karyotype showed $2 \mathrm{n}=4 \mathrm{x}=44$ chromosomes. Thus, $P$. guineense has four chromosome sets, in accordance with the basic chromosome number of Psidium $(\mathrm{x}=11)$. In addition, karyomorphometric analysis revealed morphologically identical chromosome groups in the karyotype of $P$. guineense. The high transferability of microsatellites $(98.6 \%)$ further corroborates with phylogenetic relationship between $P$. guajava and P. guineense. Based on the data regarding nuclear genome size, karyotype morphometry and molecular markers of $P$. guineense and $P$. guajava $(2 \mathrm{C}=0.95 \mathrm{pg}, 2 \mathrm{n}=2 \mathrm{x}=22$ chromosomes $)$, $P$. guineense is a tetraploid species. These data reveal the role of euploidy in the diversification of the genus Psidium.
\end{abstract}

Copyright Anelise Machado Marques et al. This is an open access article distributed under the terms of the Creative Commons Attribution License (CC BY 4.0), which permits unrestricted use, distribution, and reproduction in any medium, provided the original author and source are credited. 


\section{Keywords}

Psidium, polyploidy, karyotype evolution, cytogenetic, flow cytometry, SSR markers

\section{Introduction}

Psidium Linnaeus, 1753 is a genus of Myrtaceae that comprises about 92 species (Govaerts et al. 2013), predominantly distributed in the Neotropics. The species of this genus differ from those belonging to other Myrtaceae genera by seeds with bony testa, cochlear embryo with small cotyledons and large hypocotyl (Landrum and Kawasaki 1997). Brazil is a relevant center of Psidium species diversity, comprising approximately 60 taxa widely distributed in different biomes (Sobral et al. 2014). The genus is economically important (Rai et al. 2010), with Psidium guajava Linnaeus, 1753, Psidium cattleyanum Sabine, 1821 and Psidium guineense Swartz, 1788 being the most relevant commercial species for fruit production and/or source of compounds in the pharmaceutical industry. Of these taxa, P. cattleianum (Costa and Forni-Martins 2007, Costa et al. 2008, Souza et al. 2015) and P. guajava (Costa and Forni-Martins 2007, Coser et al. 2012) are the best-known species with regard to cytogenetic features.

Karyotypic characterization has been applied to better understand the changes that occur during genome evolution (Éder-Silva et al. 2007). Based on previous cytogenetic studies, euploidy has led to diversification in Psidium (Briggs and Walters 1997). In fact, a series of euploid organisms, such as diploid $(2 \mathrm{n}=22)$, tetraploid $(2 \mathrm{n}=44)$, hexaploid $(2 \mathrm{n}=66)$ and octoploid $(2 \mathrm{n}=88)$ species (Atchison 1947, Costa and ForniMartins 2006a, 2006b, 2007), derived from the basic $x=11$ chromosome number (Atchison 1947, Costa et al. 2008), has been reported for the genus. Nevertheless, the relationship among species that arose from euploidy events is still poorly understood in Psidium.

According to current knowledge, few Psidium species are diploid $(2 \mathrm{n}=22)$, such as Psidium chinense Loudon, 1830 (Naitani and Srivastava 1965), Psidium friedrichsthalianum Niedenzu, 1893 and P. guajava, which is the only diploid species whose karyotype has been characterized (Coser et al. 2012). Considering that the genus Psidium shows polyploid species $(2 \mathrm{n}=44-88$ chromosomes), the allo- and/or autopolyploidization in diploid species of this genus can be related to the occurrence of polyploidy. Thus, the chromosome number and karyotype characterization of the polyploid species represents the basis to understand the origin and diversification in Psidium.

Euploid species are key models for evolution because they provide evidence of the polyploidization event that promoted diversification and speciation. Considering that, this study aimed to refine the knowledge about karyological aspects of Psidium guineense. Besides, a comparison was performed with the diploid species $(2 \mathrm{x}=22) P$. guajava, because this species is the only of the Psidium genus characterized from flow cytometry (FCM), cytogenetic (Coser et al. 2012) and molecular markers (Risterucci et al. 2005, Guavamap 2008, Nogueira et al. 2015). 


\section{Material and methods}

Psidium guajava fruits were obtained from 50 plants growing in orchards located in different regions of the Brazil. Psidium guineense fruits were obtained from indigenous populations occurring in Atlantic Forest remnants located in the Municipalities of Alegre (four individuals), Itapemirim (three individuals), Santa Teresa (seven individuals), and Conceição da Barra (six individuals), all located in Espírito Santo state. The sampling was done between 2012 and 2014.

FCM and molecular analyses were conducted with the same 50 individuals of $P$. guajava and 20 of $P$. guineense. Due to FCM results, karyotype characterization was performed using seeds obtained from ten distinct plants of the two species. Solanum lycopersicum Linnaeus, 1753, 'Stupické' (reference standard for FCM, 2C $=2.00$ picograms - pg; Praça-Fontes et al. 2011) seeds were supplied by Dr. Jaroslav Doležel (Experimental Institute of Botany - Czech Republic).

\section{C nuclear measurement}

Leaves were collected from $S$. lycopersicum (standard), P. guajava and P. guineense (samples). Nuclei suspensions were obtained from leaf fragments of the standard and of each sample, according to a previously described protocol (Otto 1990, Coser et al. 2012). These suspensions were analyzed in a Partec PAS ${ }^{\ominus}$ flow cytometer (Partec ${ }^{\circ}$ $\mathrm{GmbH}$, Munster - Germany) equipped with a laser source (488 nm). Nuclei-emitted propidium iodide fluorescence was collected by an RG 610-nm band-pass filter. The equipment was calibrated for linearity and aligned with microbeads and standard solutions according to the manufacturer's recommendations. FloMax software (Partec ${ }^{\circ}$ ) was used for the data analysis. Six independent replicates were performed for each individual, with over 10,000 nuclei analyzed per replicate. The mean $2 \mathrm{C}$ values of $P$. guajava and $P$. guineense were calculated by dividing the mean channel of the $\mathrm{G}_{0} / \mathrm{G}_{1}$ fluorescence peak for the reference standard by the mean channel of the $G_{0} / G_{1}$ peak for each sample.

\section{Karyotype characterization}

Seeds of $P$. guineense and $P$. guajava were germinated in Petri dishes containing distilled water $\left(\mathrm{dH}_{2} \mathrm{O}\right)$ at $30^{\circ} \mathrm{C}$. The roots showing $1.0-2.0 \mathrm{~cm}$ in length were treated for a period of 4,15 or $19 \mathrm{~h}$ with the microtubule-inhibiting agents amiprophos-methyl (APM, Nihon Bayer Agrochem K. K. ${ }^{\circ}$ ) or oryzalin (ORY, Sigma ${ }^{\circ}$ ) at a final concentration of $4 \mu \mathrm{M}$. Subsequently, the roots were washed with $\mathrm{dH}_{2} \mathrm{O}$ for $20 \mathrm{~min}$, then fixed in fresh methanol:acetic acid $\left(\mathrm{Merck}^{\circ}\right)$ solution (3:1). The fixative was changed three times, and the roots were stored at $-20{ }^{\circ} \mathrm{C}$ for $24 \mathrm{~h}$. The roots were washed and incubated for 
2:00, $2: 15$ or $2: 30 \mathrm{~h}$ at $34^{\circ} \mathrm{C}$ in pectinase solution (Sigma ${ }^{\oplus}, \mathrm{E} 6287$ ) at ratios of 1:8, $1: 10,1: 12$ or $1: 15$ (enzyme:water). Next, the roots were washed for $10 \mathrm{~min}$ in $\mathrm{dH}_{2} \mathrm{O}$, fixed once more, and stored at $-20{ }^{\circ} \mathrm{C}$ (Coser et al. 2012). Slides were prepared using the techniques of root meristem dissociation and air-drying (Carvalho et al. 2007). The slides were analyzed and the chromosome images were captured with a Media Cybernetics ${ }^{\circledR}$ Evolution ${ }^{\mathrm{TM}}$ charge-coupled device (CCD) video camera mounted on a Nikon 80i microscope (Nikon - Japan).

\section{Molecular analysis}

The genomic DNA was extracted from young leaves according to Doyle and Doyle (1990). The integrity and concentration of the DNA samples were verified using a Nanodrop $^{\mathrm{TM}}$ 2000. Amplification reactions were performed using 142 simple sequence repeat (SSR) markers (Suppl. material 1) designed for P. guajava (Risterucci et al. 2005, Guavamap 2008). Each amplification reaction consisted of $15 \mu \mathrm{L}$ of solution containing: $60 \mathrm{ng}$ DNA, $0.3 \mu \mathrm{M}$ of each primer, $1.5 \mathrm{U}$ Taq polymerase DNA (Phoneutria), $1.7 \mu \mathrm{M} \mathrm{MgCl}_{2}$ and $0.2 \mu \mathrm{M}$ dNTPs. The following program was used: denaturation at $94^{\circ} \mathrm{C}$ for $4 \mathrm{~min}$, followed by 35 cycles of denaturation at $94^{\circ} \mathrm{C}$ for $45 \mathrm{~s}$, annealing at temperature $\left(\mathrm{T}_{\mathrm{a}}\right)$ of $50^{\circ} \mathrm{C}$ or $55^{\circ} \mathrm{C}$ for $1 \mathrm{~min}$, and extension at $72{ }^{\circ} \mathrm{C}$ for $8 \mathrm{~min}$. The reactions were performed in a Veriti ${ }^{\circledR}$ 96-Well Thermal Cycler ABI. The amplification products were separated using $6 \%$ polyacrylamide gel electrophoresis, stained with ethidium bromide, and photographed using a photo-documentation system (ChemiDoc XRS + System - Bio-Rad $\left.{ }^{\mathrm{TM}}\right)$. For confirmation, up to three independent replications were performed.

\section{Results and discussion}

The FCM protocol, using isolation buffer for $10 \mathrm{~min}$ and staining buffer for $30 \mathrm{~min}$, provided peaks relative to $\mathrm{G}_{0} / \mathrm{G}_{1}$ nuclei with coefficient of variation $(\mathrm{CV})$ lower than $3.46 \%$, and thus high resolution. This result indicates that the suspensions contained sufficient number of intact, isolated and stoichiometrically stained nuclei.

Based upon the large number of plant samples of distinct genotypes evaluated in this study, the mean nuclear $2 \mathrm{C}$ value is $0.95 \mathrm{pg}$ for all P. guajava plants (Fig. 1a) and $1.85 \mathrm{pg}$ for all $P$. guineense pants (Fig. 1b). The $2 \mathrm{C}$ values of $P$. guajava and $P$. guineense are small compared with those of most angiosperms, according to reference values defined by Bennett and Leitch (2011). Similarly, low 2C DNA content values were also found in some Myrtaceae, such as the genus Eucalyptus L'Hér. 1789, which varies from 0.80 to $1.50 \mathrm{pg}$.

Psidium guajava was one of the first Myrtaceae species for which the nuclear genome size was measured using Feulgen microdensitometry. With this method, mean values of $2 \mathrm{C}=0.66 \mathrm{pg}$ (Bennett and Smith 1976) and 2C = 1.24 pg (Ohri 2002) were 

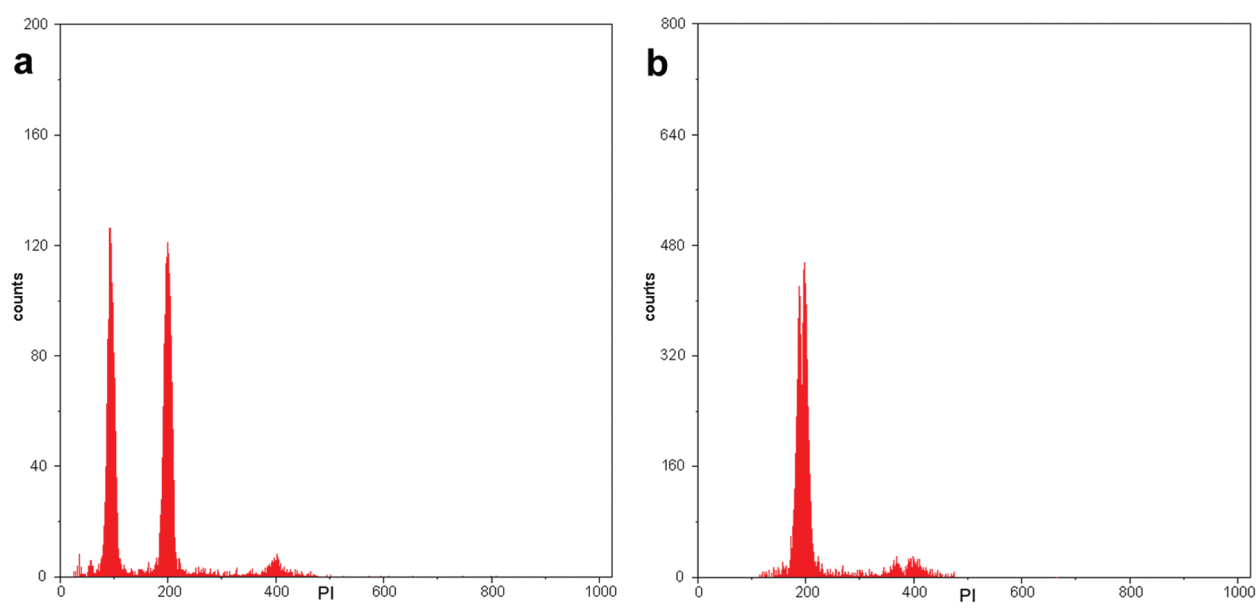

Figure I. Representative histograms obtained from FCM analysis of nuclear suspensions stained with propidium iodide. $\mathbf{A} \mathrm{G}_{0} / \mathrm{G}_{1}$ nuclei peak of the sample P. guajava $(2 \mathrm{C}=0.95 \mathrm{pg})$, positioned in channel 95, and the standard S. lycopersicum $(2 \mathrm{C}=2.00 \mathrm{pg})$ in channel $200 \mathbf{B} \mathrm{G}_{0} / \mathrm{G}_{1}$ nuclei peak of the sample P. guineense $(2 \mathrm{C}=1.85 \mathrm{pg})$, positioned in channel 185 , and the standard $S$. lycopersicum $(2 \mathrm{C}=2.00 \mathrm{pg})$ in channel 200.

obtained. Nuclear DNA content has also been measured for $P$. guajava using FCM, and the mean values were $2 \mathrm{C}=0.507 \mathrm{pg}$ ('White'), $2 \mathrm{C}=0.551 \mathrm{pg}$ ('Red', Costa et al. 2008), $2 \mathrm{C}=0.95 \mathrm{pg}$ (28 genotypes, Coser et al. 2012), $2 \mathrm{C}=0.99 \mathrm{pg}$ ('Paluma') and $2 \mathrm{C}=1.02 \mathrm{pg}$ ('Purple', Souza et al. 2015). In the present study, the $2 \mathrm{C}$ value for $P$. guineense was $2 \mathrm{C}=1.85 \mathrm{pg}$, approximately twice that observed in $P$. guajava $(2 \mathrm{C}=$ $0.95 \mathrm{pg}$ ). The $2 \mathrm{C}$ value of $P$. guineense has also been measured as $2 \mathrm{C}=2.02 \mathrm{pg}$ (Souza et al. 2015).

The distinct $2 \mathrm{C}$ values observed for $P$. guineense and $P$. guajava may be related to the different techniques, plant standards, nuclear isolation and staining procedures used. More inconsistent values of DNA content were found by Costa et al. (2008), who used Arabidopsis thaliana Linnaeus, 1753, 'Columbia' ( $2 \mathrm{C}=0.32 \mathrm{pg})$ as reference standard. The leaf of this species exhibits endopolyploidy (2C, 4C, 8C...) (Yotoko et al. 2011); thus, it is necessary to correctly check the reference $G_{0} / G_{1}$ peak to measure the $2 \mathrm{C}$ value of the sample based on the $2 \mathrm{C}$ nuclei of this standard.

Based on DNA content, the occurrence of karyotype modifications that increased the genome size may have played a role in the origin of $P$. guineense. To confirm this hypothesis, karyotypic characterization was accomplished for $P$. guineense and $P$. guajava. The root tips that were treated with $4 \mu \mathrm{M}$ APM for $15 \mathrm{~h}$ and macerated in 1:10 pectinase solution for $2 \mathrm{~h}$ provided the most adequate metaphases for morphometric analysis. Metaphases were chosen based on relevant characteristics: well-spread chromosomes with well-defined constriction, without chromatin deformations and cytoplasmic background noise. These features allowed accurate chromosome counting, morphometric characterization and assembly of the karyograms (Fig. 2, Table 1). 


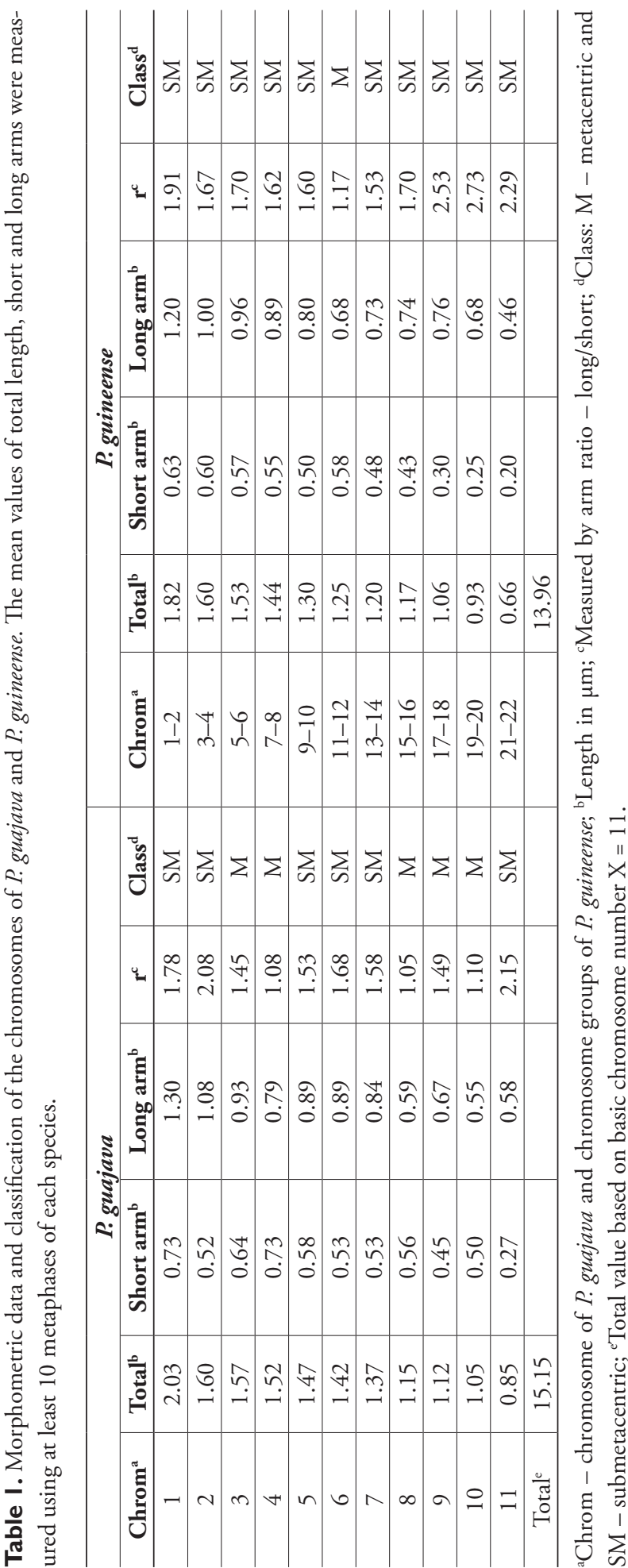




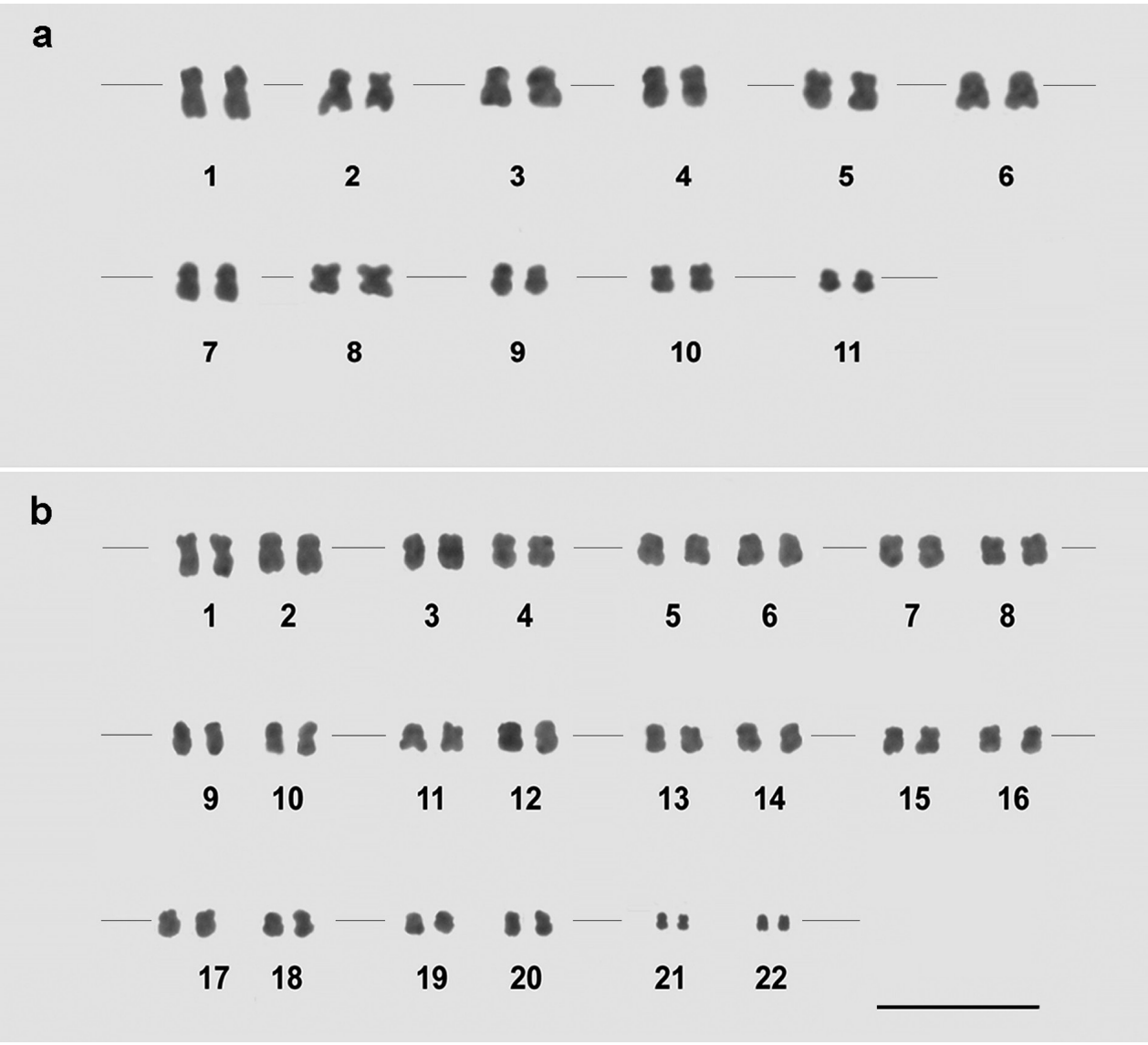

Figure 2. A $P$. guajava karyogram showing $2 \mathrm{n}=2 \mathrm{x}=22$ chromosomes, being five metacentric $(3,4,8,9,10)$ and six submetacentric pairs $(1,2,5,6,7,11)$ B $P$. guineense karyogram showing $2 \mathrm{n}=4 \mathrm{x}=44$ chromosomes, with two metacentric $(11,12)$ and twenty submetacentric pairs $(1-10,13-22)$. Note groups of morphologically identical chromosomes, such as 1 and 2, 3 and 4, 21 and 22 . Bar $=5 \mu \mathrm{m}$.

The chromosome number of $P$. guajava and of $P$. guineense were accurately determined here as $2 \mathrm{n}=2 \mathrm{x}=22$ and $2 \mathrm{n}=4 \mathrm{x}=44$, respectively (Fig. 2, Table 1). Thus, no intraspecific karyotype variations were identified for all $P$. guajava and $P$. guineense plants. Differently, other studies have reported cytotypes for $P$. guineense (Srivastava 1977) and mainly for $P$. guajava (Kumar and Ranade 1952, Majumder and Mukherjee 1972, Srivastava 1977, Costa and Forni-Martins 2006a, Éder-Silva et al. 2007, Souza et al. 2015), indicating the occurrence of an intraspecific chromosome variation related to euploidy and aneuploidy. During all period of the experiments (2012-2014), none plant exhibiting somatic chromosome number variation was recorded for both Psidium species.

Psidium guajava exhibited metacentric (pairs 3, 4, 8, 9, 10) and submetacentric chromosomes (pairs 1, 2, 5, 6, 7, 11). This species had relatively small and morphologically similar chromosomes, two of which (1 and 11) were distinguished by their 
very distinct total length. Paredes et al. (2006) reported variation in the morphometric classification of the chromosomes of some $P$. guajava genotypes, relating seven metacentric, two submetacentric and two acrocentric chromosome pairs. However, the same authors reported eight metacentric, one submetacentric and two acrocentric chromosome pairs in other genotypes. Coser et al. (2012) studied for the first time the morphometric characterization of $P$. guajava using enzymatic cellular dissociation of the roots and air-drying of the slides. The authors observed that, independently of genotype, $P$. guajava has $2 \mathrm{n}=2 \mathrm{x}=22$ chromosomes with five metacentric $(3,4,8,9$, 10) and six submetacentric pairs $(1,2,5,6,7,11)$.

As observed for $P$. guajava, the karyotype of $P$. guineense also showed only metacentric $(11,12)$ and submetacentric $(1-10,13-22)$ chromosomes (Table 1). Previous cytogenetic approaches revealed a karyotype for $P$. guineense of $2 \mathrm{n}=4 \mathrm{x}=44$ chromosomes (Chakraborti et al. 2010). Besides metacentric and submetacentric chromosomes, Chakraborti et al. (2010) also reported an acrocentric one, as well as a chromosome pair distinguished by a secondary constriction for $P$. guineense. The two latter features were not found in the present work.

The karyomorphometric analysis also revealed groups of morphologically identical chromosomes in P. guineense: 1-2, 3-4, 5-6, 7-8, 9-10, 11-12, 13-14, 15-16, 17-18, 19-20 and 21-22 (Table 1). Therefore, the cytogenetic procedures discriminated 11 chromosome groups, equivalent to the basic chromosome number of the genus Psidium. Based on total size and class, the previous study performed by Chakraborti et al. (2010) identified only four chromosome groups (A, B, C and D) for P. guineense.

Considering the basic chromosome number of Psidium ( $\mathrm{x}=11$ ) (Atchison 1947, Costa et al. 2008), the cytogenetic data suggest the origin of $P$. guineense from a polyploidization event. Therefore, the cytogenetic data confirm the FCM results in which the mean DNA contents of $P$. guajava $(2 \mathrm{C}=0.95 \mathrm{pg})$ and $P$. guineense $(2 \mathrm{C}=1.85 \mathrm{pg})$ indicate the polyploidy origin of the latter species. Polyploid species have been reported for Psidium (Atchison 1947, Andrade and Forni-Martins 1998, Costa and Forni-Martins 2006a, 2006b, 2007, Costa et al. 2008), as tetraploid (2n = 44, Psidium acutangulum Candolle, 1828, P. cattleyanum Sabine, Psidium grandifolium Candolle, 1828, Psidium friedrichsthalianum and $P$. guineense), hexaploid $(2 \mathrm{n}=66, P$. cattleyanum) and octoploid $(2 \mathrm{n}=88$, P. cattleyanum $)$ plants.

From meiotic analysis in P. guineense, Chakraborti et al. (2010) related the occurrence of 22 bivalents and, consequently, of a Mendelian segregation in anaphases. These facts and cytogenetic data found here suggest that $P$. guineense is a true allopolyploid. A true allopolyploid is a hybrid formed through reproductive cells of species with different karyotypes (Stebbins 1947). Due of this, homologous chromosomes paring in meiosis, enabling the establishment only of bivalents and the formation of viable reproductive cells. Therefore, the reproductive behavior of the true allopolyploids is like a diploid species, allowing the maintenance of the ploidy level during the generations, as observed for P. guineense (Chakraborti et al. 2010).

The variation in chromosome number seen in the genus Psidium can promote genetic isolation and possibly create barriers to gene flow (Stace 1991), leading to specia- 
tion (Briggs and Walters 1997). Polyploidy is considered one of the main mechanisms of evolution in plants (Soltis et al. 2003). Auto- or allopolyploids may exhibit genetic and phenotypic alterations compared with their ancestral species (Soltis and Soltis 1999, Mable 2003). These changes can be observed in the first generation after polyploidization or hybridization, and also along the evolutionary history of the polyploid, leading to increased diversity (Soltis and Soltis 1999, Soltis et al. 2009, Weiss-Schneeweiss et al. 2013).

Among the 142 SSR markers, 140 were amplified in P. guineense, representing 98.6\% of transferability. The high amplification rate $(98.6 \%)$ found for the $P$. guajava SSR primers in $P$. guineense showed that the annealing regions are conserved in both species, revealing the high similarity between them. This result also evidenced that these DNA sequences of $P$. guineense are very similar in relation to $P$. guajava, since values of cross-amplification of approximately $73 \%$ have been reported for species of the same genus (Barbará et al. 2007). According to Barbará et al. (2007) and Nogueira et al. (2015), the transferability rate of the SSR is higher among species phylogenetically related due to conservation of the sequences between them. Due this fact, SSR markers have been used to compare the similarity level between the genome of distinct species, allowing to analyze the phylogenetic relationship (Buschiazzo and Gemmell 2010, Meglécz et al. 2012, Nogueira et al. 2015). As well as for SSR markers, $P$. guajava and $P$. guineense exhibit strong morphological similarity between them. This fact makes it laborious to identify these species at specific level. Based on this fact, in this study, $P$. guajava and $P$. guineense were distinguished from leaf (number of veins, hairiness scattered over the abaxial leaf and adaxial) and floral (apiculus) structures.

Of the 140 primers, 117 were chosen to determine the total number of alleles, which varied from 170 for P. guineense to 148 for P. guajava (Suppl. material 1). The occurrence of three and four alleles in $P$. guineense for $9.6 \%$ of the primers in comparison to $3.4 \%$ in $P$. guajava $(2 \mathrm{x}=22)$ corroborates the polyploid origin of $P$. guineense $(4 \mathrm{x}=44)$ evidenced by nuclear DNA content and karyotype. Besides that, the molecular data reveal the occurrence of some duplicated sequences, such as the 316 and 422 SSR loci (Suppl. material 1), which showed three allele forms in both species. Based on these results, SSR markers can be considered an important complementary tool to study the genome evolution in Psidium, as is already the case for investigating the genome of vertebrates (Buschiazzo and Gemmell 2010).

This study points to the tetraploidy origin of $P$. guineense. These results reveal the importance of combining cytogenetic and molecular markers for a better understanding of how euploid events have influenced the speciation process in angiosperms.

\section{Acknowledgements}

The authors are grateful to Conselho Nacional de Desenvolvimento Científico e Tecnológico (CNPq, Brasília - DF, Brazil), Fundação de Amparo à Pesquisa do Espírito Santo (FAPES, Vitória - ES, Brazil), Fundaçáo de Amparo à Pesquisa do Estado de Minas Gerais (FAPEMIG, Belo Horizonte - MG, Brazil), and Coordenação de Aperfeiçoamento de Pessoal de Nível Superior (CAPES, Brasília - DF, Brazil) for financial support. 


\section{References}

Andrade FG, Forni-Martins ER (1998) Estudos cromossômicos em espécies de Myrtaceae. Genetics and Molecular Biology 21 (Suppl.): 166.

Atchison E (1947) Chromosome numbers in the Myrtaceae. American Journal of Botany 34: 159-164. doi: 10.2307/2437370

Barbará T, Palma-Silva C, Paggi GM, Bered F, Fay MF, Lexer C (2007) Cross-species transfer of nuclear microsatellite markers: potential and limitations. Molecular Ecology 16: 3759-3767. doi: 10.1111/j.1365-294X.2007.03439.x

Bennett MD, Leitch IJ (2011) Nuclear DNA amounts in angiosperms: targets, trends and tomorrow. Annals of Botany 107: 467-590. doi: 10.1093/aob/mcq258

Bennett MD, Smith JB (1976) Nuclear DNA amounts in angiosperms. Philosophical Transactions of the Royal Society of London Series B - Biological Sciences 274: 227-274. doi: 10.1098/rstb.1976.0044

Buschiazzo E, Gemmell NJ (2010) Conservation of human microsatellites across 450 million years of evolution. Genome Biology and Evolution 2: 153-165. doi: 10.1093/gbe/evq007

Briggs D, Walters SM (1997) Plant variation and evolution. $3^{\text {rd }}$ ed. Cambridge University Press.

Carvalho CR, Clarindo WR, Almeida PM (2007) Plant cytogenetics: still looking for the perfect mitotic chromosomes. The Nucleus 50: 453-462.

Chakraborti S, Sinha S, Sinha R (2010) Chromosome number and karyotype analysis of wild guava Psidium guineense Sw. - a new report from Tripura, India. Indian Journal of Science and Technology 3: 925-927.

Coser SM, Ferreira MFS, Ferreira A, Mitre LK, Carvalho CR, Clarindo WR (2012) Assessment of genetic diversity in Psidium guajava L. using different approaches. Scientia Horticulturae 148: 223-229. doi: 10.1016/j.scienta.2012.09.030

Costa IR, Dornelas MC, Forni-Martins ER (2008) Nuclear genome size variation in fleshy-fruited Neotropical Myrtaceae. Plant Systematics and Evolution 276: 209-217. doi: 10.1007/ s00606-008-0088-x

Costa IR, Forni-Martins ER (2006a) Chromosome studies in Brazilian species of Campomanesia Ruiz \& Pávon and Psidium L. (Myrtaceae Juss.). Caryologia 1: 7-13.

Costa IR, Forni-Martins ER (2006b) Chromosome studies in species of Eugenia, Myrciaria and Plinia (Myrtaceae) from southeastern Brazil. Australian Journal of Botany 54: 409-415. doi: 10.1071/BT04199

Costa IR, Forni-Martins ER (2007) Karyotype analysis in South American species of Myrtaceae. Botanical Journal of the Linnean Society 155: 571-580. doi: 10.1111/j.10958339.2007.00704.x

Doyle JJ, Doyle JL (1990) Isolation of plant DNA from fresh tissue. Focus 12: 13-15.

Éder-Silva E, Felix LP, Bruno RLA (2007) Citogenética de algumas espécies frutíferas nativas do nordeste do Brasil. Revista Brasileira Fruticultura, Jaboticabal 29: 110-114. doi: 10.1590/S0100-29452007000100024

Guavamap (2008) Improvement of guava: linkage mapping and QTL analysis as a basis for markerassisted selection. http://www.neiker.net/neiker/guavamap/ [accessed 04 April 2013] 
Govaerts R, Sobral M, Ashton P, Barrie F, Holst B, Landrum L, Lucas E, Matsumoto K, Mazine F, Proença C, Soares-Silva L, Wilson P, Niclughdha E (2013) World Checklist of selected plant families - Myrtaceae. The Board of Trustees of the Royal Botanic Gardens, Kew. http://apps.kew.org/wcsp/ [accessed 12 March 2013]

Kumar LSS, Ranade SG (1952) Autotriploidy in guava (Psidium guajava L.). Current Science 21: 75-76.

Landrum LR, Kawasaki ML (1997) The genera of Myrtaceae in Brazil : an illustrated synoptic treatment and identification keys. Brittonia 49: 508-536. doi: 10.2307/2807742

Mable BK (2003) Breaking down taxonomic barriers in polyploidy research. Trends in Plant Science 8: 582-590. doi: 10.1016/j.tplants.2003.10.006

Meglécz E, Néve G, Biffin E, Gardner MG (2012) Breakdown of phylogenetic signal: a survey of microsatellite densities in 454 shotgun sequences from 154 non model eukaryote species. Plos One 7: 1-15. doi: 10.1371/journal.pone.004086

Majumder PK, Mukherjee SK (1972) Aneuploidy in guava (Psidium guajava L.) I. Mechanism of variation in chromosome number. Cytologia 37: 541-548. doi: 10.1508/cytologia.37.541

Naitani SP, Srivastava HC (1965) Preliminary cytogenetical studies in Psidium chinense. Current Science 18: 536-537.

Nogueira AM, Ferreira A, Silva-Ferreira MF (2015) Transferability of microsatellites from Psidium guajava to Eugenia, Myrciaria, Campomanesia, and Syzygium species (Myrtaceae). Plant Molecular Biology Reports. doi: 10.1007/s11105-015-0921-7

Ohri D (2002) Genome size variation in some tropical hardwoods. Biologia Plantarum 45: 455-457. doi: 10.1023/A:1016290222360

Otto FJ (1990) DAPI staining of fixed cells for high-resolution flow 670 cytometry of nuclear DNA. In: Darzynkiewiez Z, Crissman HA, 671 Robinson JP (Ed.) Methods in cell biology, vol 33. Academic, 672 San Diego, 105-110.

Paredes TM, Barrios JM, Padrón AC (2006) Proceso mitótico en células radicales de Psidium spp. tolerantes, susceptibles y resistentes a Meloidogyne incognita en el estado Zulia, Venezuela. Boletín del Centro de Investigaciones Biológicas 40.

Praça-Fontes MM, Carvalho CR, Clarindo WR (2011) C-value reassessment of plant standards: an image cytometry approach. Plant Cell Reports 30: 2303-2312. doi: 10.1007/ s00299-011-1135-6

Rai MK, Asthana P, Jaiswal VS, Jaiswal U (2010) Biotechnological advances in guava (Psidium guajava L.): recent developments and prospects for further research. Trees 24: 1-12. doi: 10.1007/s00468-009-0384-2

Risterucci AM, Duval MF, Rohde W, Billotte N (2005) Isolation and characterization of microsatellite loci from Psidium guajava L. Molecular Ecology Notes 5: 745-748. doi: 10.1111/j.1471-8286.2005.01050.x

Sobral M, Proença C, Souza M, Mazine F, Lucas E (2014) Myrtaceae in lista de espécies da flora do Brasil. Jardim Botânico do Rio de Janeiro. http://floradobrasil.jbrj.gov.br/jabot/ floradobrasil/FB10853 [accessed 24 July 2014]

Soltis DE, Albert VA, Leebens-Mack J, Bell CD, Paterson AH, Zheng C, Sankoff D, Pamphilis CW, Wall CW, Soltis PS (2009) Polyploidy and angiosperm diversification. American Journal of Botany 96: 336-348. doi: 10.3732/ajb.080079 
Soltis DE, Soltis PS (1999) Polyploidy: recurrent formation and genome evolution. Trends in Ecology \& Evolution 14: 348-352. doi: 10.1016/S0169-5347(99)01638-9

Soltis DE, Solti PS, Tate JA (2003) Advances in the study of polyploidy since plant speciation.

New Phytologist 161: 173-191. doi: 10.1046/j.1469-8137.2003.00948.x

Souza AG, Resende LV, Lima IP, Martins LSS, Techio VH (2015) Chromosome number and nuclear DNA amount in Psidium spp. resistant and susceptible to Meloidogyne enterolobii and its relation with compatibility between rootstocks and commercial varieties of guava tree. Plant Systematics and Evolution 301: 231-237. doi: 10.1007/s00606-014-1068-y

Srivastava HC (1977) Cytological studies in Psidium friedrichsthalianum Niedenzu. Cytologia 42: 395-400. doi: 10.1508/cytologia.42.395

Stace CA (1991) Plant taxonomy and biosystematics. $2^{\text {nd }}$ edition, University Press, Cambridge. Stebbins GL (1947) Types of polyploids: their classification and significance. Advance Genetics 1: 403-429. doi: 10.1016/S0065-2660(08)60490-3

Weiss-Schneeweiss H, Emadzade K, Jang TS, Schneeweiss GM (2013) Evolutionary consequences, constraints and potential of polyploidy in plants. Cytogenetic and Genome Research 140: 137-150. doi: 10.1159/000351727

Yotoko KSC, Dornelas MC, Togni PD, Fonseca TC, Salzano FM, Bonatto SL, Freitas LB (2011) Does variation in genome sizes reflect adaptive or neutral processes? New clues from Passiflora. PLoS ONE 6: e18212. doi: 10.1371/journal.pone.0018212

\section{Supplementary material I}

SSR locus, annealing temperature (TA), motif, and allele number amplified in the genome of $P$. guineense and $P$. guajava.

Authors: Anelise Machado Marques, Amélia Carlos Tuler, Carlos Roberto Carvalho, Tatiana Tavares Carrijo, Marcia Flores da Silva Ferreira, Wellington Ronildo Clarindo Data type: Word document.

Explanation note: The Supplementary material 1 summarizes the SSR locus, annealing temperature (TA), motif, and allele number amplified in the genome of $P$. guineense and P. guajava.

Copyright notice: This dataset is made available under the Open Database License (http://opendatacommons.org/licenses/odbl/1.0/). The Open Database License $(\mathrm{ODbL})$ is a license agreement intended to allow users to freely share, modify, and use this Dataset while maintaining this same freedom for others, provided that the original source and author(s) are credited. 